Journal of Educational Research in Developing Areas (JEREDA)

Vol. 2. Issue 2, Pp. 173-182, 2021

http://www.jeredajournal.com

E-mail: info@jeredajournal.com

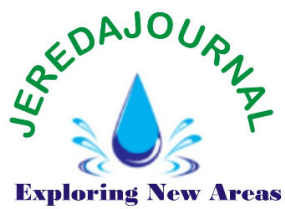

Research Article DOI:https://doi.org/10.47434/JEREDA. eISSN:2735-9107

\title{
PRINCIPALS' TRANSFORMATIONAL LEADERSHIP PRACTICES ON TEACHERS' JOB SATISFACTION AND COMMITMENTS IN ABIA STATE, NIGERIA
}

\author{
Esther Onyinyechi Iroegbulam
}

Department of Educational Administration and Planning, Abia State University, Uturu

E-mail:estheriroegbulam947@gmail.com

(D)https://orcid.org/0000-0002-8326-3628

Received: $08^{\text {th }}$ August, 2021; Revised: $20^{\text {th }}$ August, 2021; Accepted: $11^{\text {th }}$ September, 2021

ABSTRACT
Introduction: Principals are expected to exhibit the appropriate leadership skills to attract teachers to maximize input, which might be expressed in the commitment of teachers to their duties and student achievement. Principals with transformational leadership skills have the ability to create job satisfaction and also encourage teachers to be more committed to their duties.

Purpose: The study investigated the effects of transformational leadership practices of principals on the satisfaction and commitments of teachers in Abia state. The four basic elements of transformational leadership which includes; idealized influence of leaders, inspirational motivation \& ability to inspire confidence, intellectual stimulation \& creativity and individual consideration of group members were looked into.

Design: The study population consisted of 5,047 teachers and 242 principals of both rural and urban government secondary schools in Abia State. A stratified random sampling method was used at a $30 \%$ rate to obtained 73 principals and 1,514 teachers, respectively, totaling 1,587 respondents. The instrument used for the study was a questionnaire designed by the researcher titled 'Principal's Transformational Leadership Practices on Teacher Job Satisfaction and Commitments Questionnaire' (PTLPTJSCQ).

The questionnaire was administered to teachers and principals in the selected public secondary schools in Abia State. The face validity of the instrument was carried out by two experts in the field.The reliability coefficient obtained was 0.88 , and this was determined by applying test-retest reliability and Pearson's product moment correlation. Mean scores were used to answer research questions, while aggregate mean scores were used to make the final decision.

Results: Findings from the study revealed that principal's transformational leadership practices have a positive effect on teacher's job satisfaction and commitments in Abia State.

Recommendations: It was recommended that Education Ministries and Boards should establish and implement programmes such as seminars, workshops and so on to develop transformational leadership skills among school principals, among others.

Keywords: Principal, Transformational Leadership, Job satisfaction, Commitments.

\section{Cite paper as:}

Crossref Iroegbulam, E. O. (2021). Principals' transformational leadership Cited-by practices on teachers' job satisfaction and commitments in Abia state, Nigeria. Journal of Educational Research in Developing Areas, 2(2), 173182. https://doi.org/10.47434/JEREDA.2.2.2021.173.

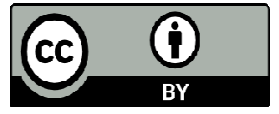

Copyright (c) 2021 The author(s) of this article retain(s) the copyright. 
Journal of Educational Research in Developing Areas (JEREDA)

Vol. 2. Issue 2, Pp. 173-182, 2021

http://www.jeredajournal.com

E-mail: info@jeredajournal.com

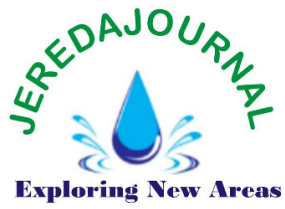

\section{PUBLIC INTEREST STATEMENT}

The study aims to reveal the importance and effectiveness of the transformational leadership style to the following: State and Federal Ministry of Education and Secondary Education Management Boards, Principals of secondary schools and other education researchers. The findings of the study will serve as guidelines to provide solutions to some administrative problems besieging the Nigerian secondary schools. The findings will also provide some insights for researchers in the field of educational leadership.

\section{INTRODUCTION}

It is obvious that the duties of teachers' center around their classroom, a room, and a chalkboard. In the traditional school system, one person leads, the other follows and one person also makes the major decisions that affect the entire group. Input maybe asked for or given but the decision itself is left up to one individual and in most cases, this one person in the case of secondary school is always the principal. According to Saleh and Kalu (2017), the principal gives direction and lead to achieve objectives, ensure the implementation of school plants with its facilities. The principal is a leader, a thinker and a decision maker. He oversees all the teachersand is the person to whom they all answer to. Uyanga, (2007) affirmed that the principal is the administrative head of secondary school who perform management functions for the actualization of educational objectives at this level of education. Principals identify and set goals and objectives of the school, which of course must be in line with the national objectives, analyse tasks and share responsibilities to the staff according to specialization and expertise. Nwosu (2007) opined that the principalis the chief executive in the secondary educational institution. In the school system, the principal has to share information, transfer ideas, and feelings through communication to enhance the collective cooperation of others within the school (Nakpodia, 2010). Ogbonnaya (2003) acknowledged that the principal is also expected to provide educational leadershipas teachers look up to him/her for educational leadership and administrative guidance. Zembylas and Papanastasiou (2004) noted that teachers' dissatisfaction with work place has been seen to be one of the problems drawing these dreams away from reality.

Teachers' job satisfaction is the fulfillment, the attractiveness and happiness teachers find in their job that makes them to be highly committed to it. Commitment is when an individual experiences responsibility for the outcome of his/her work. Committed teachers complete their tasks diligently and arealso willing to sacrifice their time and personal agenda whenever their attention is needed for the academic achievement of the school. However, Akpan (2015) observed that most teachers are not committed to their primary responsibilities. Teachers show laissez- faire attitude to school activities, some are involved in other businesses while some trade during official hours. Hence, school performance depends more on the principals' leadership than any other factor. Principals therefore are required to exhibit appropriate leadership skills to entice teachers to maximize input, which might be expressed in teachers' commitment to duty and students' academic achievements.

Leadership is a multifaceted moral relationship that exists between people as it is centred on trust, emotion, shared visions, commitments and obligation. Leadership is an act of motivating a group of people to act toward achieving a common goal. It occurs in any group or organization, in all groups a leader must emerge.Leadership could be seen as a purposeful relationship which occurs periodically among participants who use their individual skills and influence to promote transforming change (Kearns, 2005). Leadership is the ability to get things done with the help and cooperation of other people within the institution (Grace \& Kalu, 2016). Blackburn (2009) stated that leadership 
Journal of Educational Research in Developing Areas (JEREDA)

Vol. 2. Issue 2, Pp. 173-182, 2021

http://www.jeredajournal.com

E-mail: info@jeredajournal.com

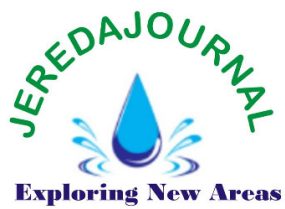

skill of school principals is often thekey factor of difference between effective and ineffective schools. Leadership is a process in which there is an element of influence. One factor that influencesteachers' commitment to their duties is the principal'sleadership practiceswhich is the most important determinant of school excellence. Traditionally speaking, some secondary school principals place emphasis on hierarchical leadership models, where top-down decision making reigns. The system directly or indirectly tells them that they do not know anything about the school administration. Maybe that is the major reason why in developing countries such as Nigeria, there is a high rate of teacher attrition.

Transformational leadership practices stimulate followers into productivity and therefore there is need to accommodate transformational leadership practices in the secondary school system. Transformational leadership practices involve a change. Change cannot just happen in schools but it happens with people. So, in order to initiate change, one needs to know how to lead people. This leadership style is what the presentgeneration needs if the desired progress could be achieved in secondary schools. It is the type of leadership that will change, revolutionize and transform progressively the lives and developmental process of people, institution, organization or nation. Hence, it involves a committed relationship between the leader and followers. It has been highlighted that leaders and subordinates in transformational leadership styles should raise each other's awareness of the goals and objectives of an organization (Kalu et al., 2019). According to Harris-Boundy (2015), transformational leadership nurtures innovation and originality, and improve job performance. Krishnan (2005) opined that the main premise of transformational leadership practice is the leader's ability to motivate followers to accomplish more than what followers planned to accomplish. Transformational leadership in schools is when the principal empowers teachers to improve

within. The principal does not simply run schools or merely keep the school afloat, she also seeks to make thingsbetter through genuine collaborations between her teachers and the stakeholders. She stimulates and inspires herteachersto both achieve extra ordinary outcomes and in the process, develop their own leadership capacity. Charry (2012) opined that leaders of this style often have high ethical and moral standards. The principal as a transformational leader creates the culture of innovation and motivates teachers and students to continuously progress, ever aiming to create the best learning environment.

Furthermore, through strong vision and personality the principal is able to inspire her teachers to change expectations, perceptions, and motivations to work in order to achieve academic excellence. Transformational leaders stimulate the efforts of their followers to be innovative, creative, reframe problems and approach old situations in new ways. Burns (2008) statedthat transformational leader motivates his team to be effective and efficient "He who thinketh he leadeth and hath no one following him is only taking a walk". The four basic elements of transformational leadership identified by Bernard Bass in 1985 are:

Idealized influence of leaders: This refers to role modelling, articulation of high expectations and confidence in followers.The transformational leader displays a charismatic personalitythat influences others to be like him. The principal should act as a role model and express willingness to take visits and follow a core set of values, convictions and ethical principles in the actions she takes. It is through this concept of idealized influence that the principal builds trust with his teachers and the teachers in turn develop confidence in her. The principal should also demonstrate the highest level of ethical behaviour possible, admitting when she is wrong and acting in a socially respectable and appropriate way. 
Journal of Educational Research in Developing Areas (JEREDA)

Vol. 2. Issue 2, Pp. 173-182, 2021

http://www.jeredajournal.com

E-mail: info@jeredajournal.com

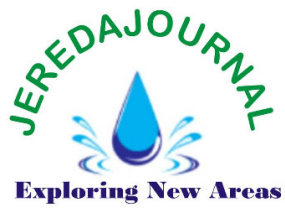

\begin{abstract}
Inspirational motivation \& ability to inspire confidence: The leader is expected to articulate a clear vision for the future, communicate expectations of the group, and demonstrate a commitment to the goal through one-onone coaching and mentoring.Inspirational motivation refers to the principal's ability to inspire confidence, motivation, and a sense of purpose in her teachers. The principal should also provide opportunities for in-service training for her teachers for them to grow and become fulfilled in their job. She should also motivate and direct her teachers to use their energy towards maximizing the attainment of instructional goals and objectives.
\end{abstract}

\section{Intellectual stimulation and creativity: This refers to encouraging} followers to challenge existing approaches, reframe problems, and think in new ways. The vision the transformational leader conveys helpsfollowers see thebig picture and succeed in their efforts. Anjali and Anand (2015) asserted that intellectual stimulation leads to the development of employee commitment to the organization. They further stated that this has implications for the ability of the organization to achieve goals based on the dedication and hard work of employees. The principal as the transformational leader should support her teachers by involving them in decision making process and stimulate their efforts to be as creative and innovative as possible to identify solutions. She solicits ideas from her teachers without critics. She also helps to change the way the teachers thinks about and frame problems and obstacles.

Individualizedconsideration of group members: The transformational leader recognizes that each follower or group member has specific needs and desires. She should also take into account the differences and perspectives of the followers and be a coach and mentor to them. For instance, some are motivated by money while others by position and excitements. As a transformational leader, the principal should be able to recognize or determine through eaves dropping or observation what motivates each individual teacher so that they will perform well. A satisfied teacher is invariably an effective and efficient teacher. When a teacher is not satisfied, his/herclassroom could be drastically and negatively affected. Satisfaction connotes happiness and a state of wellbeingas an outcome of a need fulfilled. When teachers are satisfied with their job, they carry out their duties in high spirit. Warrilow (2011) noted that when workers are satisfied in their jobs, they perform better and this is an indication of school effectiveness.

Egbezor (2005) observed that it can be argued that dedication to duty is a function of job satisfaction and job satisfaction here refers to the extent to which personal wants both materially and psychologically realized by the individual while performing a task. Job satisfaction offers explanation of what makes people want to come to work, what makes them happy about their jobs or whatmakes them decide to quit their job. Udoeke (2005) opined that if the school system is to succeed and if the huge investments and national hopes on education are to be fully achieved, the teacher must have enough job satisfaction. Teachers that have job satisfaction are committed to duties. It is the school principal who will effectively maximize the available human and material resources by the commitment process to achieve the educational goals. Hence, when teachers are committed to their job, they are bond emotionally and intellectually to their duties.

\section{STATEMENT OF THE PROBLEM}

In recent times, there has been an outcry about the declining quality of the secondary education system products in Abia State. The cause of the drop, in standards is not unrelated to teacher lack of job satisfaction and commitment to duties. Teachers showlaissez-faire attitude to school activities, come to school late, lack discipline, engage in examination malpractices, participate in other businesses that distract their 
Journal of Educational Research in Developing Areas (JEREDA)

Vol. 2. Issue 2, Pp. 173-182, 2021

http://www.jeredajournal.com

E-mail: info@jeredajournal.com

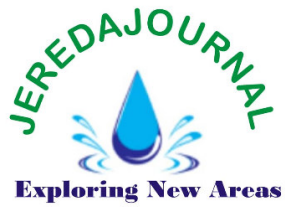

attention from teaching, some even trade during official hours, and so on. It is obvious that a satisfied teacher is invariably an effective and efficient teacher. The principal being the sole administrator of secondary schools have series of responsibilities to perform in order to move the school forward. Ozaralli (2003) affirmed that principals with transformational leadership skills have the ability to create situations that encourage teachers to internalize school goals. Abu-Hassain and Essawi (2014) further stated that transformational leadership is more potent than other leadership styles because it occurs when one or more teachers engage with others in such a way that administrators and teachers raise one another to higher level of commitment, dedication and morality. This implies that the type of leadership style adopted by theprincipal determines the teachers' job satisfaction and commitments to their duties.

\section{PURPOSE OF THE STUDY}

The main purpose of this study was to investigate the effects of transformational leadership practices of principals on teacher job satisfaction and commitments in Abia state. Specifically, the study sought to investigate the following:

1. Ways the transformational leadership practices of principals improve the satisfaction of the job and commitments of teachers in Abia State.

2. The influence of transformational leadership practices of the principal on teachers' job satisfaction and commitments in Abia State.

\section{RESEARCH QUESTIONS}

1. In what ways do transformational leadership practices of principals improve teachers' job satisfaction and commitments in Abia State?

2. To what extent do transformational leadership practices of principals influence teachersjob satisfaction and commitments in Abia State?

\section{METHODOLOGY Research Design} The study adopted survey research design. According to Emaikwu (2014), survey research design is a form of descriptive research that gathers data from a large number of subjects. The study meets the requirement for survey research design because the researcher is only interested in gathering data about the variables rather than information about the individuals.

\section{Population and Sample}

The total population for the study was 5,289 and this comprised 242 principals and 5,047 teachers from both rural and urban secondary schools in Abia State. A stratified random sampling technique was used to draw the number of principals and teachersat $30 \%$ rate to get 73 principals and 1,514 teachers respectively, totalling 1,587 respondents used for the study.

\section{Procedure of data collection}

The instrument for data collection was a structured questionnaire titled "Principals'Transformational Leadership Practices on Teachers' Job Satisfaction and Commitments Questionnaire (PTLPTJSCQ)". The questionnaire comprised of sections $A$ and $B$. Section A contained personal data such as sex, status, years of experience and location of schools while Section B contains questionnaire items which provided answers to the research questions. This section contained 20 items structured on a four point modified likert scale of Strongly Agreed (SA), Agreed (A), Disagreed (D) and Strongly Disagreed (SD) weighted 4, 3, 2, and 1 respectively.

The instrument was validated by two experts from Measurement and Evaluation and EducationAdministration and Planning. The instrument was administered to the respondents in the sampled schools with the help of research assistance in each school. The completed questionnaire was collected at the spot to ensure high percentage rate of return. The reliability coefficient $(r)$ of the instrument obtained was 0.88 , which 
Journal of Educational Research in Developing Areas (JEREDA)

Vol. 2. Issue 2, Pp. 173-182, 2021

http://www.jeredajournal.com

E-mail: info@jeredajournal.com

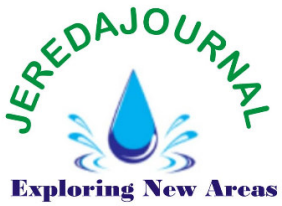

was determined through the application of test-retest reliability and Pearson Moment Correlationthat involved 20 respondents outside the sample size of the total population.

\section{Method of Data Analysis}

While answering the research questions, if the weighted mean scores of a questionnaire item are equal or greater than the mean score of the criterion of 2.50, it implies that the respondent 'agreed' with the items. On the contrary, if the weighted mean scores of a

questionnaire item is less than the criterion mean scores of 2.50, the respondent 'disagreed' with the items. Furthermore, the aggregated mean scores obtained from the weighted mean scores gave the final decision of therespondents.

Research Question One: In what ways do transformational leadership practices of principals improve teacher job satisfaction and commitments in Abia State?

Table 1: Mean Scores of Principals and Teachers on Ways that Transformational Leadership Practices of Principals Enhance Teacher Satisfaction with Work and Commitments.

\begin{tabular}{|c|c|c|c|c|c|c|}
\hline $\mathbf{S} / \mathbf{N}$ & Items & \multicolumn{2}{|c|}{$\begin{array}{l}\text { Principals } \\
\mathrm{n}_{1}=73\end{array}$} & $\begin{array}{l}\text { Teacher } \\
n_{2}=1,514\end{array}$ & $\begin{array}{l}\text { Weighted } \\
\text { mean }\end{array}$ & Remarks \\
\hline 1. & $\begin{array}{l}\text { Create qualityinstructional } \\
\text { environment for effective teaching } \\
\text { and learning. }\end{array}$ & 3.19 & & 3.18 & 3.19 & Agreed \\
\hline 2. & $\begin{array}{l}\text { Ensuring that the problems } \\
\text { affecting the teachers are solved. } \\
\text { Ensuring that teachers are }\end{array}$ & 2.99 & & 3.29 & 3.13 & Agreed \\
\hline 3. & involved in decision making. & 3.25 & & 3.27 & 3.26 & Agreed \\
\hline 4. & $\begin{array}{l}\text { Imposition of additional duties to } \\
\text { teachers by the principals }\end{array}$ & 1.89 & & 1.69 & 1.79 & Disagreed \\
\hline 5. & $\begin{array}{l}\text { Encourage a good working } \\
\text { relationship among teachers. } \\
\text { Encouraging a democratic }\end{array}$ & 3.14 & & 3.34 & 3.24 & Agreed \\
\hline 6. & $\begin{array}{l}\text { environment for effective } \\
\text { teaching. }\end{array}$ & 2.85 & & 3.52 & 3.19 & Agreed \\
\hline 7. & $\begin{array}{l}\text { Allow teachers to get on with their } \\
\text { work as they like. }\end{array}$ & 1.75 & & 1.68 & 1.72 & Disagreed \\
\hline 8. & $\begin{array}{l}\text { Being very supportive to all } \\
\text { teachers in their professional } \\
\text { development through in-service } \\
\text { training. }\end{array}$ & 2.96 & & 3.50 & 3.23 & Agreed \\
\hline 9. & $\begin{array}{l}\text { Ensure regular payment of } \\
\text { salaries and wages. }\end{array}$ & 3.38 & & 3.48 & 3.43 & Agreed \\
\hline 10. & & 3.32 & & 3.05 & 3.19 & Agreed \\
\hline & Aggregate mean & & \multirow{2}{*}{\multicolumn{4}{|c|}{$\begin{array}{l}\text { 2.94 } \\
\text { mean scores of } 3.19,3.13,3.26,3.24, \\
3.19,3.23,3.43 \text { and } 3.19 \text { respectively, } \\
\text { which are above the criterion mean of } \\
2.50 . \text { On the other hand, items } 4 \text { and } 7 \\
\text { with weighted mean scores of } 1.79 \text { and } \\
1.72 \text { are below the criterion mean scores } \\
\text { of } 2.50 \text {. The aggregate mean scores of } \\
2.94 \text { showed that both principals and } \\
\text { teachers agreed that transformational }\end{array}$}} \\
\hline \multicolumn{3}{|c|}{$\begin{array}{l}\text { The data in Table } 1 \text { present the } \\
\text { mean scores of principals and teachers in } \\
\text { rural and urban secondary schools on } \\
\text { ways that transformational leadership } \\
\text { practices of principals improve teacher } \\
\text { job satisfaction and communities in Abia } \\
\text { State. Both respondents agreed onitems } \\
1,2,3,5,6,8,9 \text { and } 10 \text { with weighted }\end{array}$} & & & & \\
\hline \multicolumn{3}{|c|}{ Volume 2 , Number 2} & & & & $8 \mid \mathrm{P}$ a g e \\
\hline
\end{tabular}


Journal of Educational Research in Developing Areas (JEREDA)

Vol. 2. Issue 2, Pp. 173-182, 2021

http://www.jeredajournal.com

E-mail: info@jeredajournal.com

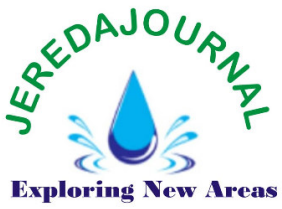

leadership practices of principals have ways of enhancing teacher job satisfaction and commitments in Abia State. Based on the analysed data, quality instructional environment, involving teachers in decision making, good working relationship among teachers, democratic environment, professional development of teachers and

so on enhance teachers job satisfaction and commitments.

Research Question 2: To what extent do transformational leadership practices of principals influence teacher job satisfaction and commitments in Abia State.

Table 2: Mean Scores of Principals and Teachers on influence of Principals'Transformational leadership PracticesandTeachers'Job Satisfaction and Commitments.

\begin{tabular}{|c|c|c|c|c|c|}
\hline $\mathbf{S} / \mathbf{N}$ & Items & $\begin{array}{l}\text { Principals } \\
\left(N_{1}=73\right)\end{array}$ & $\begin{array}{l}\text { Teachers } \\
\left(N_{2}=1514\right)\end{array}$ & $\begin{array}{l}\text { Weighted } \\
\text { mean }\end{array}$ & Remarks \\
\hline 1. & $\begin{array}{l}\text { Encourage teachers to develop } \\
\text { new techniques for self-growth } \\
\text { and school development. }\end{array}$ & 3.36 & 3.19 & 3.28 & Agreed \\
\hline 2. & $\begin{array}{l}\text { Allow clear communication with } \\
\text { teachers. }\end{array}$ & 3.44 & 3.30 & 3.37 & Agreed \\
\hline 3. & $\begin{array}{l}\text { Create confidence in staff for } \\
\text { research and development }\end{array}$ & 3.10 & 2.90 & 3.00 & Agreed \\
\hline 4. & $\begin{array}{l}\text { Encourage teachers to make } \\
\text { school related decisions that will } \\
\text { move the school forward. }\end{array}$ & 3.15 & 3.34 & 3.25 & Agreed \\
\hline 5. & $\begin{array}{l}\text { Principal exhibit absolute control } \\
\text { on his teachers. }\end{array}$ & 1.77 & 2.01 & 1.89 & Disagreed \\
\hline 6. & $\begin{array}{l}\text { Encourage little or no supervision } \\
\text { of academic activities in the } \\
\text { school. }\end{array}$ & 1.85 & 1.69 & 1.77 & Disagreed \\
\hline 7. & $\begin{array}{l}\text { Enhance thecommitment of } \\
\text { teachersto their duties. }\end{array}$ & 3.32 & 3.39 & 3.36 & Agreed \\
\hline 8. & $\begin{array}{l}\text { Increases the efficiency of staff } \\
\text { for onward transfer of the needed } \\
\text { skills/ideas in students. }\end{array}$ & 2.93 & 3.44 & 3.19 & Agreed \\
\hline 9. & Encourage lazy attitude to work. & 1.81 & 1.57 & 1.69 & Disagreed \\
\hline 10. & $\begin{array}{l}\text { Motivate teachers to develop } \\
\text { creative and innovative skills. }\end{array}$ & 3.19 & 3.27 & 3.23 & Agreed \\
\hline
\end{tabular}

Aggregate mean score

2.80

Data in Table 2 present the mean score of principals and teachers in urban and rural public schools on the influence of transformational leadership practices of principals and the job satisfaction and commitments in Abia State. Both respondents agreed with items 11,12 , $13,14,17,18$ and 20 with weighted mean scores of $3.28,3.37,3.00,3.25$, $3.36,3.19$ and 3.23 respectively. These are accepted because they are above the mean criterion 2.50. However, items 15, 16 and 19 with weighted means of 1.82 , 1.77 and 1.69 are rejected because they are below the criterion mean of 2.50 . The aggregate mean score of 2.80 revealed that principals transformational leadership practices has positive influence on teachers' job satisfaction and commitments in Abia State. Therefore, encouraging teachers to develop new self-growth techniques, allowing a clear communication channel, motivating teachers to develop creative and innovative skills, etc., has a positive influence on the satisfaction and commitment of the job of teachers. 
Journal of Educational Research in Developing Areas (JEREDA)

Vol. 2. Issue 2, Pp. 173-182, 2021

http://www.jeredajournal.com

E-mail: info@jeredajournal.com

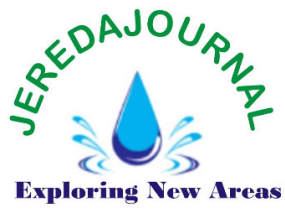

\section{DISCUSSIONS}

From the findings, it was very obvious that both the principals and teachers agreed that principals' transformational leadership practices have great influence on teachers job satisfaction and commitment. In research question one which stated 'in what ways do principals transformational leadership practices enhance teachers job satisfaction and commitment in Abia State? The findings revealed that both principals and teachers agreed that there are ways through which principal transformational leadership practices can improve teacher satisfaction and commitment. This implies that a democratic climate for effective teaching, regular pay of salaries and wages, ensures regular promotion, and therefore does not enhance the satisfaction and commitment. The study is in agreement with recent study by Khan et al. (2020) on impact of transformational leadership on work performance, burnout, and social loafing: A mediation model was revealed, using a population of 308 respondents from public schools in Malaysia, that the four transformational leadership factors had a significant relationship with the commitment of teachers to their duties. Organizational leaders must have transformational attributes by being well informed about their employees, because a transformational leader can inspire the employee to achieve anticipated or significant outcomes. Udoeke (2005), Egbezor (2005), Money (2017) expressed similar view. If the schools are to succeed and if the huge investments and national hopes on education are to be fully achieved, teachers must have enough job satisfaction.

Furthermore, in a similar study conducted by Money (2017) on the effectiveness of transformational leadership style in secondary schools in Nigeria, using a sample population of 40 principals and 400 teachers chosen by stratified and simple random sampling method from 50 schools across the sixpolitical zones of Nigeria. The result revealed that both principals and teachers are aware of transformational leadership styles; however, it was doubtful if the practical aspect of transforming the followers and students are realized.Boon et al. (2006), Pepper (2010), Sergiovanni (2007) and Uche, Nwabueze and Ememe (2009), expressed similar opinion that encouraging teachers to develop new techniques for selfgrowth, clear channel of communication, motivate teachers to develop creative andinnovative skills and so on have positive influence on teachers job satisfaction and commitment.

\section{CONCLUSION}

The quality of theleadership style of the principal makes the difference between the success and failure of the school. However, one of the major challenges toprincipals' leadership style adopted for the success of the school is teachers' job satisfaction and commitments to their duties. When teachers are not satisfied with their jobs as a result ofnon-payment of salaries and wages, not involving them in decision making, lack of professional development to enhance their knowledgeand so on, they will not be committed to their duties.A classroom teacher who derives the satisfaction of his job is expected to be punctual in school and perform his duties diligently in an adequate learning environment and instructional facilities. A satisfied teacher is invariably an effective and efficient teacher. It is imperative that the principals of public secondary schools in Abia State adopt a transformational leadership style for the success of their schools.

\section{RECOMMENDATIONS}

Based on the findings of the study, the following recommendations were made:

1. The state government should ensure that teachers' salaries and wages are paid when due.

2. School principals should ensure there is quality instructional environment for effective teachingand learning in their schools.

3. The state governmentshould encourage development programmes such as seminars, workshops, conferences and so on for secondary 
Journal of Educational Research in Developing Areas (JEREDA)

Vol. 2. Issue 2, Pp. 173-182, 2021

http://www.jeredajournal.com

E-mail: info@jeredajournal.com

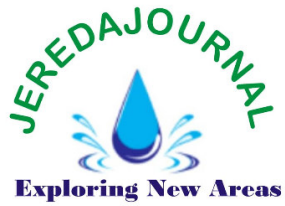

school teachers to up-date their knowledge.

4. School principals should allow clear communication with their teachers.

5. Transformational leadership practices should be adopted in all secondary education systems.

6. The state government should ensure that secondary school teachers' welfare should be considered adequately to enable them put in their best.

Conflicts of Interest: The author declares that there is no conflict of interest.

\section{Author's Bio note}

Dr. Esther Onyinyechi Iroegbulam is a teacher in Abia State Secondary Education Management Board, Umuahia, Abia State. She had written and coauthored different chapters and articles in different textbooks and academic journals. She is a member of Nigeria Union of Teachers (NUT), Teachers Registration Council of Nigeria (TRCN), Nigerian Association for Educational Administration and Planning (NAEAP) and Gender Studies Association of Nigeria (GSAN).

\section{Disclaimer Statement}

I hereby declare that this study is the product of my own research efforts and has not been presented elsewhere for publication. All sources have been duly distinguished and appropriately acknowledged.

\section{References}

Abu, H., \& Essawi, M. (2014).Value orientation and leadership styles among secondary school principals in Isreali's Arap Education System. International Journal of Bussinss Administration, 5 (3), 49-58.

Anjali, K. T., \& Anand, D. (2015). Intellectual stimulation and job commitment: Acase study of IT professional. IUP Journal of Organizational Behaviour, 14(2), 28-41.

Blackburn, D. (2009). Socio-cultural leadership: The art of restructuring schools through research-based principal leadership. BooktopiaPty Ltd.

Boon, O. K., Arumugam, N., \& Vellapan, Y. (2006). A quantitative analysis of the link between organizational culture and job satisfaction: Evidence from some Malaysian Healthcare Organization. Malaysian Management Review, 41(1), 68-90.

Burns, J. M. (2008). Transforming leadership: A new pursuit of happiness. Atlantic monthly press.

Charry, K. (2012). Leadership theories-8 major leadership theories. http://Psychology.about.com/od/l eadership/p/lead theories.htm.

Egbezor, O. (2005). The theories of job satisfaction and productivity. Lola Educational Publishers.

Emaikwu, S. O. (2014).Foundation of research methods and statistics. Selfers Academic Press Ltd.

Grace, S. O.,\&Kalu, C.O. (2016).Educational Administration and planning.Concepts, theories and practice. Immaculate prints.

Harris-Boundy, J. (2015). Transformational leadership for employee creativity. Academy of management proceedings, 2015 (1), 19162. http//doi.org/10.5465/ambpp. 2015.19162.

Kalu, D. C., Okpokwasili, N. P., \& Ndo, M. B. (2019). Challenges faced by leaders in improving the job satisfaction of subordinates. Information impact. Journalof Information and Knowledge Management, $9 \quad$ (3), 151. http://doi.org/10.4314/iiji.v9i3.12

Kearns, M. A. (2005). An x-ray of old and modern leadership: Challenges and prospects. Bliss Prints.

Khan et al., (2020). Impact of transformational leadership on work performance, burnout and social loafing: A mediation model.Future Business Journal, 6(1), 40- 
Journal of Educational Research in Developing Areas (JEREDA)

Vol. 2. Issue 2, Pp. 173-182, 2021

http://www.jeredajournal.com

E-mail: info@jeredajournal.com

50.https://doi.org/10.1186/s4303 $-020-00043-8$

Krishnan, V. R. (2005). Transformational leadership and outcomes: Role of relationship duration. Leadership and Organizational Journal, 26(5/6), 442-457.

Money, V. O. (2017). Effectiveness of transformational leadership style in secondary schools in Nigeria. Journal of Education and Practice, 8 (9), 34-45.

Nakpodia, E.D. (2010). Influence of communication on administration of secondary schools in Delta State, Nigeria. International NGO Journal, 5(8), 194-198.

Nwosu, O. (2007). Educational administration: Strategies, synergies and social calculus. Osyora Nigeria Limited.

Ogbonnaya, N. O. (2003). Principles and applications of Educational Policies.Nsukkauniversity trust publishers.

Ozaralli, N. (2003). Effects of transformational leadership on empowerment and team effectiveness. Leadership and Organization Development Journal, 24, 335-344.

Saleh, A. D.,\&Kalu, C. O. (2017).Historical development of education in Nigeria. Ayas publishers.

Sergiovanni, T. (2007). Rethinking leadership. A collection of articles ( $\left.2^{\text {nd }} e d.\right)$. Carwu press.

Uche, C. M., Nwabueze, A. I., \& Ememe, O. N. (2009). Developing entrepreneurial skills among university students: A tool for attaining millennium development goals in south-south states of Nigeria. African Journal of Educational Research and Development (AJERD).3 (2), 5464.

Udoeke, B. B. (2005). The management of educational personnel in schools. Total Publishers Ltd.

Uyanya, A. E. (2007). The principal and education reform agenda of the Nigeria Economic Empowerment Development Strategy (NEEDs).
Paper presented at the $2^{\text {nd }}$ Annual National Conference of Association for Encouraging Qualitative Education in Nigeria (ASSEQEN). $9^{\text {th }}-11^{\text {th }}$ May.

Warrilow, S. (2011).Transformational leadership theory: The4 key components in leading change \& managing change.

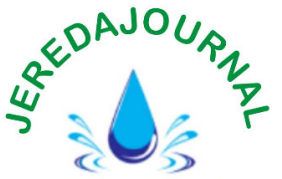

Exploring New Areas 